\title{
The Effect of Different Learning Method on the Visual Reaction Time of Hand and Leg in High School Level Tennis Trainees
}

\author{
Yahya Y1ldırım (Corresponding author) \\ Department of Common Courses, Bursa Technical University, Bursa, Turkey \\ Tel: 90-546-278-2025Ｅ-mail: yahya.yildirim@btu.edu.tr
}

Ali K1zılet

Faculty of Sport Sciences, Marmara University, Istanbul, Turkey

Tel: 90-532-488-8666Ｅ-mail: akizilet@gmail.com

Received: November 19, 2020

Published: December 30, 2020

doi:10.5296/jei.v6i2.17970
Accepted: December 15, 2020

URL: https://doi.org/10.5296/jei.v6i2.17970

\begin{abstract}
The aim of this study is; to investigate the effects of differential training method on hand and leg visual reaction time in high school tennis trainees. 24 trainees (12 girls, 12 boys) attending a tennis course in a high school participated in the study voluntarily. It was determined that the mean age of the participants was $15.00 \pm 0.00$ years, their body weight was $63.46 \pm 10.64 \mathrm{~kg}$, their height was $1.65 \pm 0.06 \mathrm{~m}$, and their body mass index was $23.26 \pm 2.91$. According to the results of the pre-tests, 2 homogeneous groups of 12 people were created. One group formed the Differential Group (DG), the other the Traditional Group (TG), and each group included 6 girls and 6 boys. The training sessions were held 3 days a week (90 minutes each) and lasted 10 weeks in total. In the study, the visual reaction time (separately for hand and leg) was performed as a pre-test and a post-test using the Fitlight Trainer $^{\mathrm{TM}}$ device. Paired Sample t test was used to examine the difference between pre-test and post-test of the same group. Independent Sample t test was used to measure the intergroup interaction between pre-tests and post-tests. To interpret the statistical significance level, $p<0.05$ was accepted. As a conclusion; it was observed that both training methods shorten the visual reaction time, but there was no significant difference between the groups in pre-test and post-tests.
\end{abstract}


Keywords: High school, Tennis, Differential learning, Reaction time

\section{Introduction}

In recent years, traditional teaching methods have been questioned in skill teaching and studies have been carried out on methods that can be more effective (Henz \& Schöllhorn, 2016). But studies on new teaching methods are still not enough (Rivera \& Badillo, 2019).

While skills are being demonstrated during competition, athletes are exposed to a wide variety of conditions, so diversity is required in training to achieve conditions close to the competition (Frank et al., 2008). Many studies in the literature have shown that training with variable applications is more effective in learning compared to classical training (Hegen \& Schöllhorn, 2012; Savelsbergh et al., 2010; Lattwein et al., 2014; Humpert \& Schöllhorn, 2006).

In order to improve athlete performance, it is important to apply innovative methods apart from classical methods. One of these innovative methods is the differential training method (Schöllhorn, 2000). In this method, there is no room for frequent repetitions and corrective feedback. In the training process, skills are applied with different body movements, different floors, different equipment and by restricting the perceptions of the athletes to confuse the mind (Schöllhorn et al., 2012). Studies in the literature show that differential training is more effective in learning than traditional methods (Müller et al., 2009).

Interest in tennis and parallel to this, competition between athletes is increasing day by day (Pluim et al., 2007). This situation has made training practices even more important. Tennis sport requires many technical and physical properties for successful performance (Reid \& Schneiker, 2008). Tennis is usually an emergency game because it is necessary to respond to the balls sent by the opponent continuously and urgently. Therefore, short reaction time is very important for tennis players. Tennis players must react to the opponent's moves as quickly as possible (Reid et al., 2013).

Reaction time is the time between a person's perception of a stimulus and the onset of a conscious response to that stimulus (Schimidt, 1991). The athlete with the better reaction time is likely to be superior to those with the same technical capacities. Reaction time is one of the key factors of success in many sports branches and it has been aimed to shorten this feature with many years of work (Göral et al., 2012).

The aim of this study is to examine the effects of differential learning method on the visual reaction time of tennis players. The reason we examine the visual reaction time is; that a visual cue is more specific to tennis than auditory stimulus (Kovacs, 2014). Our first hypothesis; both training methods will be effective in shortening the visual reaction time of hand-leg. Our second hypothesis; compared to traditional methods, differential training will be more effective in shortening the reaction time measured with both hands and legs. 


\section{Macrothink}

\section{Method}

\subsection{Participants}

The trainees who have been attending a tennis course for 2 weeks in a high school were informed about the study. 24 trainees (12 girls, 12 boys) who had not done sports before participated in the study voluntarily. As a result of the pre-tests, 2 homogeneous groups of 12 people were created (Differential Group (DG) and Traditional Group (TG)). There were 6 girls and 6 boys in each group.

The descriptive information of the participants is given in Table 1. All participants are the same age $(15.00 \pm 0.00$ years). Participants' height was measured with a stadiometer $(0.1 \mathrm{~cm}$ sensitive) and body weight was measured with a digital scale ( $0.1 \mathrm{~kg}$ sensitive) (Sanz et al., 2019). The parents of the participants were informed about the study and their written consents were obtained. The volunteer consent form prepared in accordance with the Declaration of Helsinki was filled in to the participants. Approval of the Marmara University Institute of Health Sciences Ethics Committee was obtained for the study (Date/number; 02.04.2018/126).

Table 1. Descriptive statistics (mean $\pm \mathrm{SD})$

\begin{tabular}{|l|l|l|l|}
\hline Group & Body height $(\mathrm{m})$ & Body weight $(\mathrm{kg})$ & BMI $\left(\mathrm{kg} / \mathrm{m}^{2}\right)$ \\
\hline DG $(\mathrm{n}=12)$ & $1.66 \pm 0.06$ & $62.72 \pm 11.68$ & $22.60 \pm 3.06$ \\
\hline TG $(\mathrm{n}=12)$ & $1.64 \pm 0.05$ & $64.20 \pm 9.96$ & $23.90 \pm 2.72$ \\
\hline Total $(\mathrm{n}=24)$ & $1.65 \pm 0.06$ & $63.46 \pm 10.64$ & $23.26 \pm 2.91$ \\
\hline
\end{tabular}

Note. Differential group (DG), traditional group (TG), body bass index (BMI).

\subsection{Measurements}

The tests were applied in the gym, which is not exposed to much light. In the last 24 hours before the test, the participants did not do any strenuous physical activity. In the last 3 hours before the test, the participants did not take any food or drink except water. Before the tests, 10-15 minutes of warm-up and stretching were done. The tests were applied twice, at the beginning and end of the 10-week study. Fitlight Trainer $^{\mathrm{TM}}$ (FitLight Sports Corp, Ontario, Canada) device was used to measure hand and leg visual reaction time (Fitlight Trainer $^{\mathrm{TM}}$, 2020).

\subsubsection{Hand Reaction Test}

Five Fitlight lights are mounted on the wall shown in figure 1 . Two lights at $1 \mathrm{~m}$ height and 3 $\mathrm{m}$ spacing, two lights $1 \mathrm{~m}$ above them, and one more light $50 \mathrm{~cm}$ above the middle of these two lights. The placement of the lights is adjusted to suit forehand, backhand, forehand volley, backhand volley and smash. The participant waited in the basic stance position of tennis with 


\section{Macrothink}

a tennis racket in his hand at the middle level of the lights and $1 \mathrm{~m}$ behind the wall, and extinguished it by moving his racket to the red lights 10 times at 1 second intervals. Each light is set to remain on for 5 seconds and another light comes on 1 second after it is turned off. The lights are adjusted to detect the racket from a distance of $10 \mathrm{~cm}$. Each participant was given a trial, then 2 tests were performed at 2-minute intervals, and the best of these 2 tests was recorded and used in the analysis (Zwierko et al., 2014).

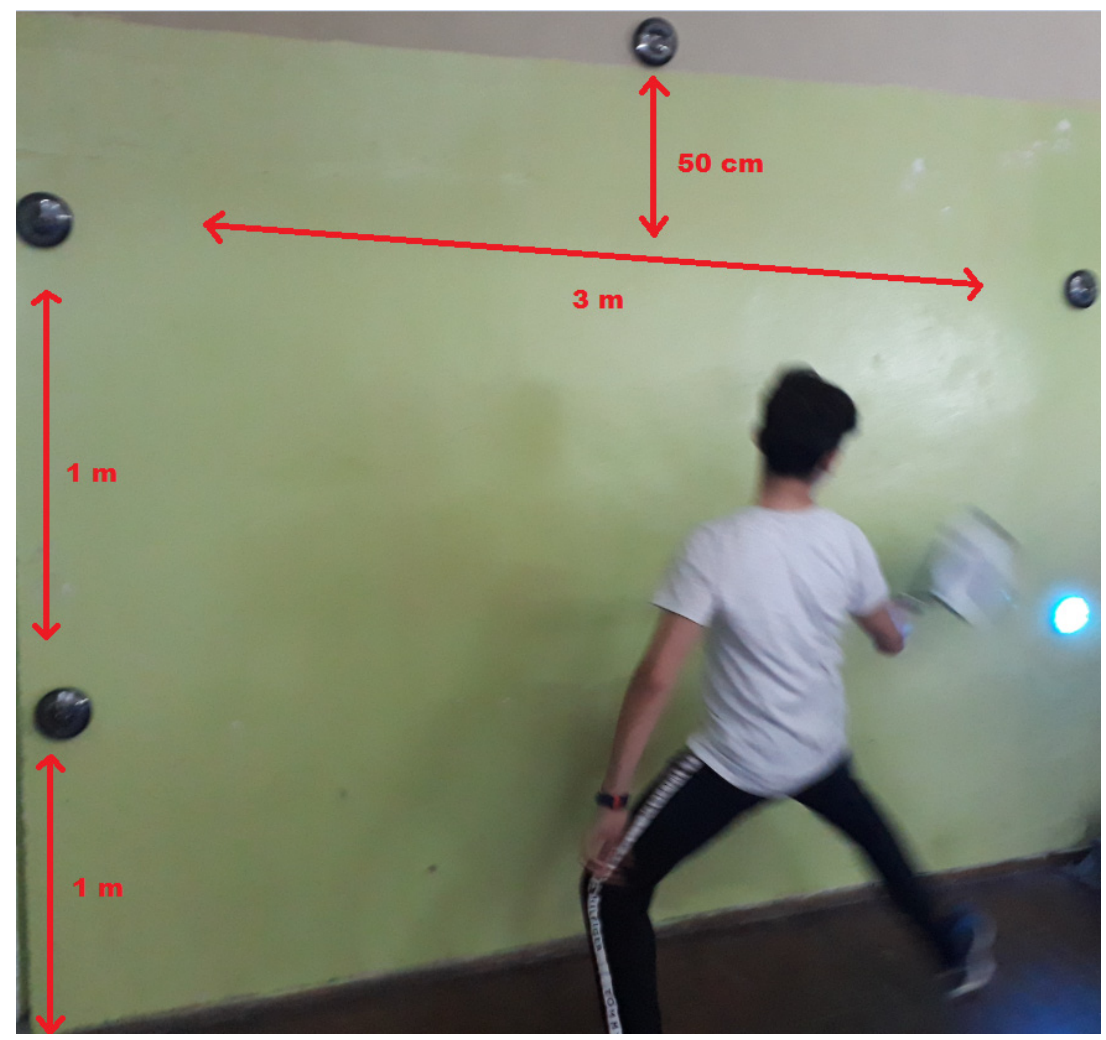

Figure 1. Hand reaction test

\subsubsection{Leg Reaction Test}

Five Fitlight lights are fixed on the ground as shown in figure 2 . Two lights are placed $50 \mathrm{~cm}$ to the right and left of the point where the participant will stop, two lights $50 \mathrm{~cm}$ ahead of these two lights, and one light $50 \mathrm{~cm}$ ahead of the participant's stop. The participant stood standing in the middle of the lights and extinguished the lights, which were lit in red 10 times at 1 second intervals, with one leg. Each light is set to remain on for 5 seconds and another light comes on 1 second after it is turned off. The lights are adjusted to detect the foot from a distance of $10 \mathrm{~cm}$. Each participant was given a trial, then 2 tests were performed at 2-minute intervals, and the best of these 2 tests was recorded and used in the analysis (Zwierko et al., 2014). 


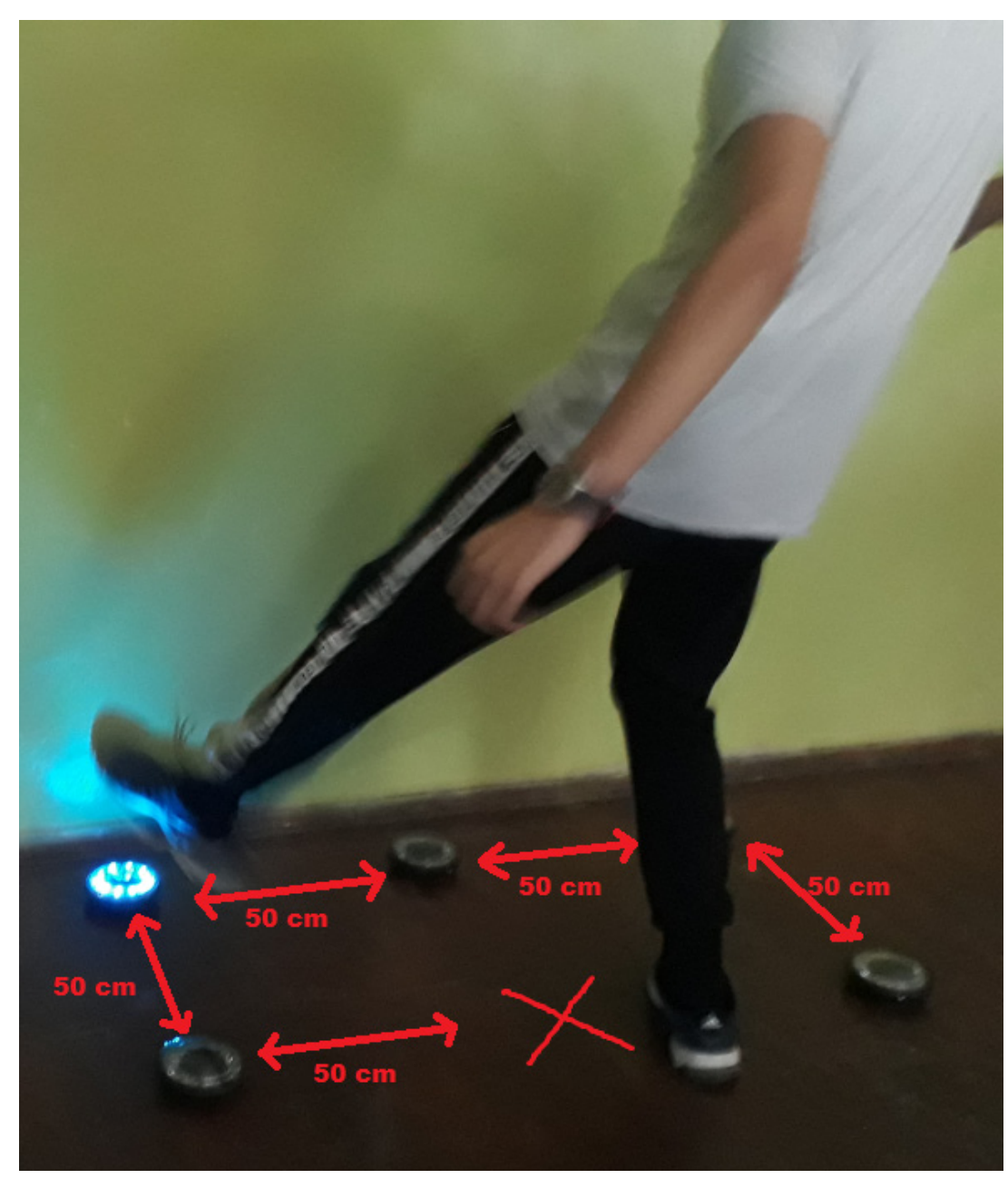

Figure 2. Leg reaction test

\subsection{Study Design}

In both groups, 90-minute training sessions were used 3 days a week for 10 weeks. Both groups were trained by 2 physical education teachers with a second level tennis coaching certificate. DG was given tennis training with differential teaching method. According to the differentiation principles of Schöllhorn, different body movements, perceptual differences and different equipment have been added to tennis strike techniques and applied on different floors. Frequent repetition and corrective feedback avoided (Schöllhorn, 1999). Differentiation principles can be seen in figure 3. Traditional tennis teaching methods were used in TG. A standard training environment with frequent repetitive and corrective feedbacks was applied. At the beginning and at the end of the training, both groups had the same warm-up and streching time and content. 


\begin{tabular}{|c|c|c|}
\hline $\begin{array}{l}\text { Hits with different } \\
\text { body movements }\end{array}$ & Hits reducing perceptions & $\begin{array}{l}\text { Hits with using Different } \\
\text { equipments and floors }\end{array}$ \\
\hline $\begin{array}{l}\text { - Bending the body in different } \\
\text { directions before hitting } \\
\text { - Hits by extending one arm in } \\
\text { different directions } \\
\text { - Hits on one leg } \\
\text { - Sitting/kneeling hits } \\
\text { - Rotation around one's own body } \\
\text { after hits } \\
\text { - Double foot jumping up during } \\
\text { the hits } \\
\text { - The racket goes in different } \\
\text { directions after the hits, doesn't } \\
\text { follow the ball }\end{array}$ & $\begin{array}{l}\text { - Hits with one eye closed } \\
\text { - Using the glove to reduce the } \\
\text { feel of the racket grip } \\
\text { - Hits with earplugs } \\
\text { - Hits on the bosu ball and balance } \\
\text { pad }\end{array}$ & $\begin{array}{l}\text { - Using different objects as } \\
\text { rackets (sticks, balls, etc.) } \\
\text { - Using different objects as balls } \\
\text { (elastic ball, crazy ball, table } \\
\text { tennis ball and wrinkled paper) } \\
\text { - Playing on different floors } \\
\text { (cobblestone floor, gym mat floor, } \\
\text { etc.) }\end{array}$ \\
\hline
\end{tabular}

Figure 3. Differentiation principles in differential learning (Schöllhorn, 1999)

\subsection{Statistical Analysis}

SPSS 20.0 program was used for data analysis. It was observed that the groups showed normal distribution. An independent sample $t$ test was used to analyze the mean differences between groups. Paired sample t test was used to examine the score differences in the pre-test and post-tests of the same group. For statistical significance level $p<0.05$ was accepted.

\section{Findings}

Hand reaction time is given in Table 2, leg reaction time pre-test and post-test measurement results are given in Table 3. Paired sample $t$ test and independent sample $t$ test analyzes are presented together in both tables.

As a result of the pre-test, there is no statistically significant difference between the groups in the means of hand reaction time $(\mathrm{t}=0.082, \mathrm{p}=0.935>0.05)$. There is no statistically significant difference between the groups as a result of the post-test $(\mathrm{t}=-0.416, \mathrm{p}=0.681>$ $0.05)$. When looking at the average differences between pre-test and post-test within each group; significant decrease in DL $(\mathrm{t}=3.303, \mathrm{p}=0.007<0.05)$ and significant decrease in TG $(\mathrm{t}=2.908, \mathrm{p}=0.014<0.05)$ were observed (Table 2$)$. 
Table 2. The results of paired sample $t$ test and independent sample $t$ test of hand reaction time in DG and TG groups

\begin{tabular}{|c|c|c|c|c|c|c|}
\hline \multirow{2}{*}{\multicolumn{2}{|c|}{ Group }} & Pre-test & Post-test & \multicolumn{3}{|c|}{ Paired Sample T Test } \\
\hline & & Mean (s) & Mean (s) & Mean Difference (s) & $\mathrm{t}$ & $\mathrm{p}$ \\
\hline \multicolumn{2}{|l|}{$\mathrm{DG}(\mathrm{n}=12)$} & $0.849 \pm 0.132$ & $0.765 \pm 0.140$ & $0.084 \pm 0.088$ & 3.303 & $0.007 *$ \\
\hline \multicolumn{2}{|l|}{$\mathrm{TG}(\mathrm{n}=12)$} & $0.845 \pm 0.115$ & $0.788 \pm 0.124$ & $0.057 \pm 0.069$ & 2.908 & $0.014 *$ \\
\hline \multirow{2}{*}{ Independent $\mathrm{T}$ Test } & $\mathrm{t}$ & 0.082 & -0.416 & & & \\
\hline & $\mathrm{p}$ & 0.935 & 0.681 & & & \\
\hline
\end{tabular}

Note. Differential group (DG), traditional Group (TG), second (s), * = significant difference $(\mathrm{p}<0.05)$.

When looking at the pre-test and post-test results, there was no statistically significant difference between the groups in the mean leg reaction time (pre-test; $\mathrm{t}=-0.217, \mathrm{p}=0.830>$ 0.05 , post-test; $\mathrm{t}=0.773, \mathrm{p}=0.448>0.05$ ). When looking at the average difference between pre-test and post-test of the same group; in both groups, a statistically significant decrease was observed in leg reaction times from pre-test to post-test $(\mathrm{DG} ; \mathrm{t}=2.686, \mathrm{p}=0.021<0.05$, TG; $\mathrm{t}=4.079, \mathrm{p}=0.002<0.05$ (Table 3).

Table 3. The results of paired sample $t$ test and independent sample $t$ test of leg reaction time in DG and TG groups

\begin{tabular}{|c|c|c|c|c|c|c|}
\hline \multirow{2}{*}{\multicolumn{2}{|c|}{ Group }} & Pre-test & Post-test & \multicolumn{3}{|c|}{ Paired Sample T Test } \\
\hline & & Mean (s) & Mean (s) & Mean Difference (s) & $\mathrm{t}$ & $\mathrm{p}$ \\
\hline \multicolumn{2}{|l|}{$\mathrm{DG}(\mathrm{n}=12)$} & $0.630 \pm 0.077$ & $0.576 \pm 0.094$ & $0.054 \pm 0.070$ & 2.686 & $0.021^{*}$ \\
\hline \multicolumn{2}{|l|}{$\mathrm{TG}(\mathrm{n}=12)$} & $0.638 \pm 0.092$ & $0.548 \pm 0.080$ & $0.090 \pm 0.076$ & 4.079 & $0.002 *$ \\
\hline \multirow{2}{*}{ Independent $\mathrm{T}$ Test } & $\mathrm{t}$ & -0.217 & 0.773 & & & \\
\hline & $\mathrm{p}$ & 0.830 & 0.448 & & & \\
\hline
\end{tabular}

Note. Differential group (DG), traditional Group (TG), second (s), * = significant difference $(\mathrm{p}<0.05)$.

\section{Discussion and Conclusion}

In this study, it was aimed to investigate the effects of differential training method in shortening the visual reaction time of hand and leg in high school tennis trainees compared to traditional methods. Our hypotheses; both training methods will shorten the reaction time and 
differential method will shorten the reaction time more than traditional methods.

The results of the study support our first hypothesis. In other words, 10 weeks of tennis training performed with both differential learning method and traditional teaching method significantly shortened the visual reaction times of hands and leg. There are many studies in the literature showing the positive effect of tennis training on reaction time. In one study, it was stated that 12-week tennis training shortened the visual and auditory reaction time (Karagöz, 2008). As a result of another study, it was concluded that with exercise, responses to external environmental stimuli become faster (Mouelhi et al., 2006). In another study, it was stated that two months of mini tennis training had a positive effect on reaction time (Özer \& Aslan, 2018). These studies in the literature gave results parallel to our research.

The results obtained from the study do not support our second hypothesis. As a result of the analyzes made with visual reaction time measurements taken with both hands and leg, when the pre-tests and post-tests were compared in DG and TG, no statistically significant difference was found between the groups. Because both methods shorten the reaction time at a similar level. Studies investigating the effect of learning on reaction time are limited in the literature. In a previous study; it was reported that the reaction times of football players given differential learning training shortened more than the control group (Reuss, 2013). In the literature, there are many studies showing that differential learning is more effective on performance improvement than traditional education (Henz \& Schöllhorn, 2016; Frank et al., 2008; Schöllhorn et al., 2006). In a study on ball control and goal kick in football, it was reported that the differential group gave more successful results than the traditional group (Schöllhorn et al., 2012). In a study on ball throwing skill in handball, the advantages of differential learning method were reported (Wagner \& Muller, 2008). These studies in the literature contradict our study in terms of comparing differential and traditional learning methods. It is thought that the involvement of skill learning practice in our study and the feedbacks that are widely used in traditional teaching cause this result. It is recommended that studies on the reaction time be conducted by differentiating.

As a consequence; tennis training for 10 weeks in both groups significantly shortened the visual reaction times of hands and leg. Moreover, it can be said that differential and traditional methods affect the visual reaction time in tennis players in a similar way.

Differential teaching can reveal original movement patterns as it deviates from repetitive standard practices and allows different applications in varying conditions (Torrents et al., 2007). Moreover, not including too many repetitions in the same pattern in this method can prevent boredom in athletes (Yıldırım et al., 2020).

\section{Acknowledgements}

Marmara University Scientific Research Projects Coordination Unit supported this work with the grant number "SAG-C-DRP-110718-0438".

\section{References}

Fitlight Trainer $^{\mathrm{TM}}$. (2019). Retrieved November 18, 2020, from https://www.fitlight 
training.com

Frank, T. D., Michelbrink, M., Beckmann, H., \& Schöllhorn, W. I. (2008). A quantitative dynamical systems approach to differential learning: Self-organization principle and order parameter equations. Biological Cybernetics, 98, 19-31. https://doi.org/10.1007/s00422007-0193-x

Göral, K., Saygın, Ö., \& İrez, G. B. (2012). Profesyonel futbolcuların oynadıkları mevkilere göre görsel ve işitsel reaksiyon sürelerinin incelenmesi. Selçuk Üniversitesi Beden Eğitimi ve Spor Bilimleri Dergisi, 14(1), 5-11.

Hegen, P., \& Schöllhorn, W. I. (2012). Lernen an unterschieden und nicht durch wiederholungen. Fussballtraining,; 3: 30-37

Henz, D., \& Schöllhorw, W. I. (2016). Differential training facilitates early consolidation in motor learning. Front Behav Neurosci, 10, 199. https://doi.org/10.3389/fnbeh.2016.00199

Humpert, V., \& Schöllhorn, W. I. (2006). Vergleich von techniktrainingsansätzen zum tennisaufschlag. In A. Ferrauti \& H. Remmert (Eds.), Trainingswissenschaft im freizeitsport (pp. 121-124). Hamburg: Czwalina.

Karagöz, Ş. (2008). 8-10 Yaş Arası Çocuklarda 12 Haftalık Tenis Antrenmanlarının Görsel ve İsitsel Reaksiyon Zamanina Etkisinin Incelenmesi (Master's Thesis, Afyon Kocatepe University Institute of Health Sciences, Afyonkarahisar).

Kovacs, M. S. (2009). Movement for tennis: The importance of lateral training. Strength \& Conditioning Journal, 31(4), 77-85. https://doi.org/10.1519/SSC.0b013e3181afe806

Lattwein, M., Henz, D., \& Schöllhorn, W. I. (2014). Differential training as an intervention strategy to prevent choking under pressure in basketball freethrow. In A. De Haan, C. J. De Ruiter, \& E. Tsolakidis (Eds.), Book of Abstract of the 19th Annual Congress of the European College of Sport Science (p. 610). Amsterdam, Utrecht: Digital Printing Partners.

Mouelhi, G. S., Bouzaouach, I., \& Tenenbaum, G. (2006). Simple and choice reaction times under varying levels of physical load in high skilled fencers. J Sports Med Phys Fitness, 46(2), 344-51.

Müller, E., Lindinger, S., \& Stöggl, T. (2009). Science and skiing IV (pp. 454-460). UK: Meyer \& Meyer Sport Ltd.

Özer, U., \& Aslan, C. S. (2018). 8-11 Yaş kız çocuklarında mini tenis eğitiminin koordinasyon ve reaksiyon zamanı üzerine etkileri. Turk $J$ Sports Med, 53, 76-82.

Pluim, B. M., Miller, S., Dines, D., Renstrom, P. A., Windler, G., \& Norris, B. (2007). Sport science and medicine in tennis. British Journal of Sports Medicine, 41(11), 703-704. https://doi.org/10.1136/bjsm.2007.040865

Reid, M., \& Schneiker, K. (2008). Strength and conditioning in tennis: current research and practice. J Sci Med Sport, 11, 248-256. https://doi.org/10.1016/j.jsams.2007.05.002 


\section{Macrothink}

Reid, M., Sibte, N., Clark, S., \& Whiteside, D. (2013). Physiological tests for elite athletes (2nd ed.). Australian Institute of Sport. Champaign, IL: Human Kinetics.

Reuss, C. (2013). Aufmerksamkeit und Reaktionsgeschwindigkeit in Abhängigkeit eines Life Kinetik-Trainings bei 12-jährigen Nachwuchsathleten (Unveröffentlicht). Technische Universität Darmstadt, Fachbereich Humanwissenschaft, Institut für Sportwissenschaften.

Rivera, E. L., \& Badillo, J. J. G. (2019). Comparison of the effects of three hangboard strength and endurance training programs on grip endurance in sport climbers. Journal of Human Kinetics, 66, 183-193. https://doi.org/10.2478/hukin-2018-0057

Sanz, B., Arrieta, H., Hervas, G., Rezola-Pardo, C., Ruiz-Litago, F., Iturburu, M., ... Irazusta, J. (2019). Serum adiponectin is associated with body composition and cognitive and psychological status in older adults living in long-term nursing homes. Experimental Gerontology, 121, 1-9. https://doi.org/10.1016/j.exger.2019.03.005

Savelsbergh, G. J. P., Kamper, W. J., Rabius, J., Koning, J. J. D., \& Schöllhorn, W. (2010). A new method to learn to start in speed skating: A differencial learning approach. Int. J. Sport Psychol., 41, 415-427.

Schimidt, R. A. (1991). Motor learning and performance (pp. 18-23). Ilinois: Human Kinetics Books.

Schöllhorn, W. I. (1999). Individualität—Ein vernachlässigter parameter? Leistungssport, 29(2), 7-11.

Schöllhorn, W. I. (2000). Applications of systems dynamic principles to technique and strength training. Acta Academia Olympiquae Estoniae, 8, 67-85.

Schöllhorn, W. I., Beckmann, H., Michelbrink, M., Sechelmann, M., Trockel, M., \& Davids, K. (2006). Does noise provide a basis for the unification of motor learning theories. Int $J$ Sport Psychol, 37, 1-21.

Schöllhorn, W. I., Hegen, P., \& Davids, K. (2012). The nonlinear nature of learning-A differential learning approach. The Open Sports Sciences Journal, 5(1), 100-112. https://doi.org/10.2174/1875399X01205010100

Torrents, C., Balagué, N., Perl, J., \& Schöllhorn, W. (2007). Linear and nonlinear analysis of the traditional and differential strength training. Ugdymas Kûno Kultûra Sportas Biomedicinos Mokslai, 3(66), 39-47. https://doi.org/10.33607/bjshs.v3i66.548

Wagner, H., \& Müller, E. (2008). The effects of differential and variable training on the quality parameters of a handball throw. Sports Biomechanics, 7(1), 54-71. https://doi.org/ $10.1080 / 14763140701689822$

Y1ldırım, Y., \& Kızılet, A. (2020). Bozdoğan T. The effect of differential learning method on the international tennis number level among young tennis player candidates. Educational Research and Reviews, 15(5), 253-260. https://doi.org/10.5897/ERR2020.3919 


\section{Macrothink}

Journal of Educational Issues

ISSN 2377-2263

2020, Vol. 6, No. 2

Zwierko, T., Florkiewicz, B., Fogtman, S., \& Krzyzanowska, A. K. (2014). The ability to maintain attention during visuomotor task performance in handball players and non-athletes. Central European Journal of Sport Sciences and Medicine, 7(3), 99-106.

\section{Copyright Disclaimer}

Copyright for this article is retained by the author(s), with first publication rights granted to the journal.

This is an open-access article distributed under the terms and conditions of the Creative Commons Attribution license (http://creativecommons.org/licenses/by/3.0/). 